\title{
METABOLIZABLE PROTEIN SUPPLY ACCORDING TO THE NRC (2001) FOR DAIRY COWS GRAZING ELEPHANT GRASS
}

\author{
Tadeu Vinhas Voltolini ${ }^{1}$; Flávio Augusto Portela Santos ${ }^{2 *}$; Junio Cesar Martinez ${ }^{3}$; Hugo \\ Imaizumi ${ }^{3}$; Alexandre Vaz Pires ${ }^{2}$; Marco Antonio Penati ${ }^{2}$ \\ ${ }^{1}$ Embrapa Semi-Árido, BR 428, km 152, Zona Rural, C.P. 23 - 56302-970 - Petrolina, PE - Brasil. \\ ${ }^{2}$ USP/ESALQ - Depto. de Zootecnia, C.P. 09 - 13418-900 - Piracicaba, SP - Brasil. \\ ${ }^{3}$ USP/ESALQ - Programa de Pós-Graduação em Ciência Animal e Pastagens. \\ *Corresponding author 〈fapsanto@esalq.usp.br>
}

\begin{abstract}
Tropical pastures fertilized with nitrogen may have high crude protein $(\mathrm{CP})$ contents with high rumen degradability. High crude protein concentrates offered to cows grazing these pastures may increase feed costs without positive effects on their performance. The objectives of this trial were to evaluate the effects of increasing metabolizable protein (MP) supply beyond the NRC (2001) recommendations for mid lactating dairy cows grazing elephant grass pasture (Pennisetum purpureum Schum. cv. Napier) managed with high stocking rates. Three concentrates $\left(6.3 \mathrm{~kg} \mathrm{DM}^{-1} \mathrm{cow}^{-1} \mathrm{day}^{-1}\right)$ were evaluated: control $(17 \% \mathrm{CP})$ was adjusted in relation to MP according to the NRC (2001); the other two contained extra soybean meal, to increase the CP content to $21.2 \%(\mathrm{CP})$ and $25.0 \%(\mathrm{CP})$. Twelve multiparous Holstein cows, averaging 150 days of milk production at a rate of $19.5 \mathrm{~kg}$ of milk day $^{-1}$, were used in a $3 \times 3$ latin square design, replicated four times. Forage consumption was 11,270 $\mathrm{kg} \mathrm{DM} \mathrm{ha}{ }^{-1}$ with $34 \%$ of green leaves and $12 \% \mathrm{CP}$. Milk production, corrected to $3.5 \%$ fat, milk fat, protein, lactose and total solids contents were not affected by treatments $(P>0.05)$. Milk urea nitrogen and plasma urea nitrogen increased linearly $(P<0.05)$ as the MP supply increased. Treatments did not affect $(P>0.05)$ body weight gain, body condition score, grazing time, ruminating time, resting time, rectal temperature and respiratory rate. Crude protein content in the concentrate formulated according to NRC (2001) is adequate for mid lactating cows grazing tropical pastures.
\end{abstract}

Key words: concentrates, milk production, protein content, tropical pastures

\section{SUPRIMENTO DE PROTEÍNA METABOLIZÁVELDEACORDO COM O NRC (2001) PARA VACAS LEITEIRAS PASTEJANDO CAPIM ELEFANTE}

RESUMO: Pastagens tropicais fertilizadas com nitrogênio podem ter alto teor de proteína bruta (PB) com alta degradabilidade ruminal. O fornecimento de concentrado com alto teor de PB para vacas mantidas nestas pastagens pode aumentar os custos sem efeitos positivos no desempenho. Objetivouse avaliar os efeitos do suprimento de proteína metabolizável acima das recomendações do NRC (2001) para vacas em pastejo. Quatorze piquetes de capim elefante (Pennisetum purpureum Schum. cv. Napier) com 0,2 ha cada, foram usados em sistema de pastejo rotacionado. Três concentrados $(6,3$ $\mathrm{kg} \mathrm{MS}^{-1}$ vaca $^{-1} \mathrm{dia}^{-1}$ ) foram avaliados. O concentrado controle com 17\% PB na MS (17\% PB) foi ajustado em proteína metabolizável de acordo com o NRC (2001). Os outros dois concentrados foram formulados inclusão extra de farelo de soja para conterem 21,2 (CP) e 25\% (CP) de PB na MS. Foram usadas 12 vacas holandesas multíparas com 150 dias em lactação e produção de leite de $19,5 \mathrm{~kg}$ dia $^{-1}$, arranjadas em QL $3 \times 3$ com quatro replicatas. A massa de forragem disponível era de $11.270 \mathrm{~kg} \mathrm{MS} \mathrm{dia-1}$ com $34 \%$ de folhas verdes e $12 \%$ de PB. A produção de leite, produção de leite corrigida para 3,5\%, teores de gordura, proteína, lactose e sólidos totais não foram afetados $(P>0,05)$ pelos tratamentos. O nitrogênio uréico do leite e o nitrogênio uréico do plasma aumentaram linearmente $(P<0,05)$ com o aumento do suprimento de proteína metabolizável. Os tratamentos não afetaram $(P>0,05)$ o ganho de peso, condição corporal, tempo de pastejo, tempo de ruminação, tempo em ócio, temperatura retal e a freqüência respiratória dos animais. O teor de PB no concentrado para suprir proteína metabolizável de acordo com o NRC (2001), é adequado para vacas em terço médio de lactação, mantidas em pastagens tropicais.

Palavras-chave: concentrados, produção de leite, teor de proteína, pastagens tropicais 


\section{INTRODUCTION}

Milk production in Brazil is based primarily on pasture systems. These pastures when intensively managed, present high forage dry matter production, allowing high stocking rates during the hot rainy season (around 200 days year $^{-1}$ in most parts of the country). Cows fed exclusively tropical pastures produce only 2,500 to $3,500 \mathrm{~kg}$ of milk year ${ }^{-1}$. Supplementing concentrate for good genetic merit dairy cows raised on tropical pastures has allowed milk productions to reach 6,000 to $7,000 \mathrm{~kg}$ year ${ }^{-1}$ which more than doubled the milk production ha ${ }^{-1}$ (Santos \& Juchem, 2000; Santos et al., 2003a, 2003b). Criteria for the amount of concentrate to feeds is dependent on the genetic merit of the animals, cost of the concentrate and milk price. In most important dairy areas in the country, $1 \mathrm{~kg}$ of $18 \%$ crude protein $(\mathrm{CP})$ concentrate costs less than $1 \mathrm{~L}$ of milk (Santos et al., 2003a, 2003b).

The new metabolizable protein system (NRC, 2001) opens the possibility for fine-tuning on protein nutrition of dairy cows as compared to the old crude protein (NRC, 1978) or absorbed protein model (NRC, 1989). Diets deficient in protein affect cow performance, however, excess of protein is a waste of money and can be deleterious for cow reproductive performance and environment (NRC, 2001). Intensively managed tropical pastures contain $12 \%$ to $22 \%$ $\mathrm{CP}$ (dry basis) and 60 to $65 \%$ total digestible nutrients (TDN) (Santos et al, 2003a, 2003b). Most commercial concentrates for lactating cows in Brazil, contain 18 to $24 \%$ CP (as fed). According to NRC (2001), for cows milking 18 to $24 \mathrm{~kg} \mathrm{day}^{-1}$, fed 5 to $7 \mathrm{~kg} \mathrm{day}^{-1}$ of concentrate and grazing tropical pastures with 12 to $22 \% \mathrm{CP}$, these concentrates would supply excesses of RDP (Rumen Degradable Protein) and MP (Metabolizable Protein).
The objectives of this trial were to evaluate the effects of increasing metabolizable protein supply beyond NRC (2001) recommendations for mid lactating dairy cows grazing elephant grass pastures (Pennisetum purpureum Schum. cv. Napier).

\section{MATERIAL AND METHODS}

\section{Location}

The trial was carried out in Piracicaba, state of São Paulo, Brazil (22 $43^{\prime}$ 'S, $47^{\circ} 25^{\prime} \mathrm{W}$ and altitude of $580 \mathrm{~m}$ ), for a period of 60 days during summer, from December 2001 through February 2002. An elephant grass pasture area of 8.0 ha was divided in 40 paddocks of 0.2 ha each. Pastures were 33 years old and since their introduction they have been managed under high stocking rates ( 7 to 10 cows ha ${ }^{-1}$ during the hot rainy season). During the experimental period, the pasture was fertilized with $80 \mathrm{~kg} \mathrm{ha}^{-1} \mathrm{~N}$ every grazing cycle (40 days). Every paddock was grazed for three days and rested for 37 days. Experimental cows and other herd lactating cows grazed a new paddock every day as a first grazing group. Dry cows and heifers, grazed the paddock for the next two days as a second grazing group.

\section{Animals}

Twelve multiparous lactating Holstein and Jersey (150 DIM and $511 \mathrm{~kg}$ LBW) cows were used as experimental cows and grazed together with other 24 herd lactating cows. Stocking rate for the first grazing group was of 4.6 cows ha ${ }^{-1}$. Average LBW for the 36 cows (12 experimental +24 herd cows) was 430 $\mathrm{kg}$.

\section{Treatments}

Three treatments were compared (Table 1): control concentrate $(17.3 \% \mathrm{CP}$ as \% of DM) was formulated to supply adequate RDP and MP according

Table 1 - Chemical composition of experimental concentrates (\% Dry Matter).

\begin{tabular}{|c|c|c|c|}
\hline \multirow{2}{*}{ Feeds } & \multicolumn{3}{|c|}{ Treatments } \\
\hline & $17 \% \mathrm{CP}$ & $21 \% \mathrm{CP}$ & $25 \% \mathrm{CP}$ \\
\hline Ground dry corn & 39.41 & 34.55 & 29.80 \\
\hline Citrus pulp & 39.41 & 34.55 & 29.80 \\
\hline Urea & 1.27 & 1.27 & 1.27 \\
\hline Soybean meal & 15.08 & 24.80 & 34.30 \\
\hline Mineral mix ${ }^{1}$ & 4.83 & 4.83 & 4.83 \\
\hline \multicolumn{4}{|l|}{ Chemical composition } \\
\hline Crude protein & 17.3 & 21.2 & 25.0 \\
\hline Metabolizable energy, (Mcal kg-1) & 3.06 & 3.10 & 3.14 \\
\hline
\end{tabular}


to NRC (2001) for the average cow (19.5 kg of milk/ d); other two treatments consisted of concentrates with 21.2 and $25.0 \% \mathrm{CP}$ were formulated to supply MP beyond NRC (2001) recommendations. To increase MP contents of the diets, soybean meal content was increased in the concentrates. For diet formulation, pasture dry matter intake (DMI) was assumed to be equal to the NRC (2001) total predicted DMI minus the concentrate DMI. Cows were fed $6.3 \mathrm{~kg}$ of concentrate DM, partitioned in two equal daily meals. The ten days pre-trial milk yield was $19.5 \mathrm{~kg} \mathrm{cow}^{-1}$ day $^{-1}$, resulting in initial milk:concentrate DM ratio of 3.1:1.

\section{Statistics}

Statistical design was a $3 \times 3$ Latin Square, replicated four times. Cows were grouped in squares based on breed, milk yield and parity. Data were analyzed using the PROC GLM of SAS (1999). A contrast analysis was performed to detect a linear or quadratic effect of treatments (orthogonal contrast).

$\mathrm{T}_{\mathrm{k}}+\mathrm{R}_{\mathrm{l}}+\mathrm{e}_{\mathrm{ijk} 1}$,

The statistical model was: $\mathrm{Y}_{\mathrm{ijk}}=\mu+\mathrm{P}_{\mathrm{i}}+\mathrm{A}_{\mathrm{j}}+$ where, $\mathrm{Y}_{\mathrm{ijkl}}=$ observed variables; $\mu=$ general mean; $\mathrm{P}_{\mathrm{i}}$ $=$ effect of period $_{i}$, $\left(\right.$ where $_{i}=1,2$ e 3$) ; A_{j}=$ effect of animal ${ }_{\mathrm{j}}$, (where $\left.{ }_{\mathrm{j}}=1,2 \ldots 12\right)$; $\mathrm{T}_{\mathrm{k}}=$ effect of treatment $_{\mathrm{k}}$, (where ${ }_{\mathrm{k}}=1,2$ e 3 ); $\mathrm{R}_{1}=$ effect of replication , $\left(\right.$ where $_{1}=1,2,3$ e 4); $\mathrm{e}_{\mathrm{ijkl}}=$ experimental error of the observations $Y_{\mathrm{ijkk}}$.

\section{Cow Data Collection and Analysis}

The 60 days of the experimental period were divided into three periods of 20 days each. The first 15 days were used for cow adaptation to the treatments and the last five days were used for data collection. Cows were milked twice a day, at $7 \mathrm{~h} 00$ and 16h00. Milk production was recorded for every milking during the five days of the collection period. Milk samples were taken for every milking during the collection period and made composite per day for every cow. Milk samples were preserved with 2-bromo-2nitropropane-1-3-diol, under refrigeration for the five days of collection and then used for infra-red analysis of fat, protein, lactose, total solids, somatic cell count and milk urea $\mathrm{N}$.

Cows had access to pasture after the afternoon milking to the morning milking and from the morning milking to $12 \mathrm{~h} 00$. From $12 \mathrm{~h} 00$ to the time of the afternoon milking cows had access to a tree shaded area. Concentrate was individually fed twice a day, after and before the morning and afternoon milkings.

Blood samples from the coccigea vein or artery were taken from every cow four hours after the concentrate feeding, in the morning (around 11h00 $12 \mathrm{~h} 00$ ) of the last day of each collection period.
Samples were taken on vacuumtainers with five $\mathrm{mg}$ potassium oxalate as anticoagulant. After collection, samples were centrifuged for 20 minutes and the plasma was stored in 2-mL ependorf flasks at $-10^{\circ} \mathrm{C}$ and analyzed for urea-N (Kit N 535, Sigma Chemical Co.).

Cow body weights (BW) and body condition scores (BCS), 1 to 5 scale (Wildman et al., 1982) were taken for two consecutive days at the beginning and end of each experimental period. The lowest BW and the mean BCS values were used. Concentration of chromium in feces was estimated using chromium oxide $\left(\mathrm{Cr}_{2} \mathrm{O}_{3}\right)$ as external marker. A daily dose of $30 \mathrm{~g}$ of chromium oxide was orally fed twice a day (15 g feeding ${ }^{-1}$ ), enveloped in a $100 \%$ cellulose paper during 12 days (seven days for adaptation and five collection days) according to Aroeira et al. (1999). Grab fecal samples (100 g sample ${ }^{-1}$ ) were taken from every cow twice a day during the five collection days. Samples were combined by cow and period and stored at $10^{\circ} \mathrm{C}$. Fecal chromium concentration was determined by atomic absorption analyses (Nascimento Filho, 1999).

Behavior measures of the 12 experimental cows (grazing time, ruminating time and resting time) were taken during a $24 \mathrm{~h}$ period, within five min intervals, during the last day of every collection period. Cow activities in the way to the milking parlor, during milking and concentrate feeding period, were not computed. Rectal temperature and respiratory frequency measures were taken on the same day of the behavior measures, at $8 \mathrm{~h} 00$ and $15 \mathrm{~h} 00$.

\section{Feed Data Collection and Analysis}

The quantitative measures made on pastures were: pasture forage mass (FM) pre and post first grazing group $\left(\mathrm{kg} \mathrm{DM} \mathrm{ha}^{-1}\right)$, pasture morphological composition of forage mass pre and post first grazing group, sward height $(\mathrm{m})$ pre and post first grazing group and sward volumetric density $\left(\mathrm{kg} \mathrm{DM} \mathrm{ha} \mathrm{cm}^{-1}\right.$ ).

Forage mass pre and post grazing was measured at four randomly chosen points in the paddock, using areas of $1 \mathrm{~m}^{2}$ sampled according to Penati et al. (2001). During every experimental period, samples were collected from the three paddocks grazed just before the five-day collection period and from the five paddocks grazed during the collection period. Forage was cut to a stubble height of $20 \mathrm{~cm}$. Two $300 \mathrm{~g}$ sub samples were taken, the first was dried at $55^{\circ} \mathrm{C}$ for 48 hours in a forced air oven, for FM calculation, and the second was used for pasture morphological composition measures. Leaves, steam and dead material from the fresh sub-samples were separated, weighted and dried at $55^{\circ} \mathrm{C}$ for 48 hours in a forced air oven, 
to determine DM content. This was made for the subsamples taken every period, for pre and post-grazing paddocks.

Sward height was determined in 20 randomly points of the eight paddocks sampled every period. The tillers were measured from the ground to the inflection points of the leaves. Sward volumetric density $(\mathrm{kg}$ $\mathrm{DM} \mathrm{ha}^{-1} \mathrm{~cm}^{-1}$ ) was calculated dividing the FM before grazing by the sward height (discounting the $20-\mathrm{cm}$ stubble height) according to Balsalobre (1996).

The forage samples used for chemical composition analysis were taken as hand plucked samples from eight paddocks every period. They were dried at $55^{\circ} \mathrm{C}$ for 48 hours in forced air oven, ground in a Willey mill, first trough a $5 \mathrm{~mm}$ and then trough a 1 $\mathrm{mm}$ screen size. Composite samples of dry matter, organic matter (OM) and ether extract (EE) were determined according to AOAC (1975). The Neutral Detergent Fiber (NDF) and the acid detergent fiber (ADF) were determined using ANKOM 200 analyzer (ANKOM Technology Fairport, NY), using sodium sulphite and alfa amilase (Soest, 1994). Lignin analyses were made with addition of sulphuric acid $72 \%$ in acid detergent fiber residue according to Soest (1994).

Crude protein $(\mathrm{CP})$ was determined in an $\mathrm{N}$ analyzer (LECO FP-2000 nitrogen analyzer, Leco Instruments, Inc. St. Joseph, MI). The in vitro DM digestibility (IVDMD) was determined using a DAISY ANKOM (ANKOM Technology Fairport, NY) (Goering $\&$ Soest, 1970). Forage TDN was calculated according to NRC (2001). Samples of concentrates were taken for every batch and checked for CP (LECO FP2000 nitrogen analyzer, Leco Instruments, Inc. St. Joseph, MI) before used in the trial. Batches that did not mach the expected CP content were discharged. Concentrate samples were composite for period, dried and analyzed for DM, EE, NDF, ADF and CP determinations.

\section{RESULTS AND DISCUSSION}

Average pre grazing FM was $11,270 \mathrm{~kg} \mathrm{DM}^{-1}$ $\mathrm{ha}^{-1}$ (Table 2), indicating the high DM production potential of tropical forages, particularly elephant grass. High DM productions $\left(5,400\right.$ a $14,970 \mathrm{~kg} \mathrm{ha}^{-1}$ per grazing cycle) for elephant grass grazed every 19 to 40 days, have been reported by several authors (Balsalobre, 1996; Rosseto, 2000; Martinez, 2004; Voltolini, 2006). Brazilian dairy farmers who intensified their grazing systems, have reached stocking rates around 6 to 12 cow ha $^{-1}$ during 200 days year ${ }^{-1}$ (Corsi et al., 2001; Santos et al., 2003a, 2003b).

Despite this high production, elephant grass growing in high fertility soil, during the hot rainy summer in Brazil, presented a high proportion of stems $(63.55 \%)$ and low proportion of leaves $(33.93 \%)$ when grazed every 37 days (Table 2). Dry matter intake may be compromised by high stem content in the forage due to the lower digestibility and sward structure, making more difficult for the cow to have access to the high quality green leaves.

Based on the amount of forage "disappearing" from the sward (an average of 2,951 $\mathrm{kg}$ of leave DM and $3,037 \mathrm{~kg}$ of stem DM), the selection capacity of the cows becomes clear, which prefer leaves instead of stems. The low proportion of leaves in the pasture, makes it necessary to offer at least $30 \mathrm{~kg} \mathrm{cow}^{-1}$ of pasture DM, so the cows could have around $10 \mathrm{~kg}$ of available DM of high quality leaves, characterizing a low grazing efficiency.

Pre-grazing sward height (Table 3) was 1.72 $\mathrm{m}$. This sward height may have negative effects on pasture DMI and grazing efficiency. For intensively managed elephant grass, as sward height increased, the grazing efficiency decreased do to the increased forage consumption during the grazing activity (Hillesheim, 1987). Higher swards are also correlated with older forage, higher stem:leafe ratio, lower pas-

Table 2 - Forage mass (FM) and morphological composition of elephant grass pasture.

\begin{tabular}{|c|c|c|c|c|c|}
\hline \multirow{2}{*}{ Components } & \multicolumn{3}{|c|}{ Periods of collection } & \multirow{2}{*}{ Mean } & \multirow{2}{*}{$\mathrm{SD}^{1}$} \\
\hline & December & January & February & & \\
\hline FM pre-grazing, $\left(\mathrm{kg} \mathrm{DM}^{-1} \mathrm{ha}^{-1}\right)$ & 10,707 & 11,207 & 11,442 & 11,270 & 4,900 \\
\hline Leaves, $(\%)$ & 34.71 & 32.25 & 34.83 & 33.93 & 6.58 \\
\hline Stems, $(\%)$ & 62.39 & 64.88 & 63.37 & 63.55 & 6.76 \\
\hline Dead material, $(\%)$ & 2.90 & 2.88 & 1.80 & 2.53 & 1.42 \\
\hline FM post-grazing, $\left(\mathrm{kg} \mathrm{DM}^{-1} \mathrm{ha}^{-1}\right)$ & 3,662 & 8,122 & 4,660 & 5,481 & 2,538 \\
\hline Leaves, $(\%)$ & 12.70 & 19.28 & 15.80 & 15.93 & 4.92 \\
\hline Stems, $(\%)$ & 83.8 & 77.11 & 64.83 & 75.25 & 4.80 \\
\hline Dead material, $(\%)$ & 3.51 & 3.61 & 2.70 & 3.27 & 1.67 \\
\hline
\end{tabular}

${ }^{1}=$ Standard deviation. 
ture density and more limited animal access to high quality green leaves.

To improve the grazing efficiency and to allow the cows to have better DMI of higher quality forage the well fertilized summer elephant grass should be grazed more frequently than every 37 days. More recent data obtained in the same area suggests 1.00 $\mathrm{m}$ sward height as adequate for grazing elephant grass. This sward height was determined as the height when $95 \%$ of the light is intercepted by the forage. Silva (2005) has suggested the criteria based on $95 \%$ of light interception as being more adequate to graze tropical pastures than the criteria based on fixed resting periods. This resulted in shorter resting periods, that varied from 17 to 21 days during summer (Voltolini, 2006) and FM with better morphological composition (around $54 \%$ leaves and $42 \%$ stems) as compared with this trial (Voltolini, 2006; Carareto, 2007). Milk production per cow and stocking rate was higher for pastures grazed with $1.00 \mathrm{~m}$ height than for pastures grazed with a fixed resting period of 27 days (Voltolini, 2006; Carareto, 2007).

Pasture volumetric density is correlated with forage intake. Classical studies by Stobbs (1977) indicate that one of the major morphological aspects of the sward that could affect forage DMI is its volumetric density. In pastures with low volumetric density, animals have more difficulty to harvest the forage. This increases grazing time and may decrease DMI.
The volumetric density observed in this study was on average $74 \mathrm{~kg} \mathrm{DM} \mathrm{ha}{ }^{-1} \mathrm{~cm}^{-1}$, and is within the range reported by Balsalobre (1996), from 34.97 to $74.97 \mathrm{~kg} \mathrm{DM} \mathrm{ha} \mathrm{cm}^{-1}$. Martinez (2004) reported for the same pasture area, a higher value during the autumn period, $98.00 \mathrm{~kg} \mathrm{DM} \mathrm{ha}{ }^{-1} \mathrm{~cm}^{-1}$. These volumetric densities are considered low, representing a possible limiting factor for pasture DMI (Stobbs, 1977).

The post-grazing FM values were high $(5,481$ $\mathrm{kg} \mathrm{ha}^{-1} \mathrm{DM}$ ), with high proportion of stems $(75.25 \%)$ and low proportion of leaves (15.93\%). This means that a second group of animals grazing this area would have difficulty to reach an adequate DMI, with a consequent low performance. Again, these data suggest that this pasture should be grazed more frequently during the hot and rainy tropical summer in Brazil, as reported by Voltolini (2006).

The CP, NDF, ADF, lignin, EE and ashes (Table 4) are within the range reported by Balsalobre (1996; 2002) for tropical forages. Teixeira et al. (1999) worked with Panicum Maximum, cv. Tobiatã, intensively managed during the hot rainy season (10 to 12 cows/ha), grazed every 33 days, and reported a higher CP (14.6\%), a lower NDF (61.6\%) and a higher in vitro DM digestibility (IVDMD) (77\%) than the ones observed into the present study. Santos et al. (2003a, 2003b), summarized several data of nutrient composition for different tropical forage species managed intensively in south and southeast of Brazil. The authors

Table 3 - Sward height pre and post-grazing and sward density of elephant grass pasture grazing by lactating dairy cows.

\begin{tabular}{|c|c|c|c|c|c|}
\hline \multirow{2}{*}{ Components } & \multicolumn{3}{|c|}{ Periods of collection } & \multirow{2}{*}{ Mean } & \multirow{2}{*}{$\mathrm{SD}^{1}$} \\
\hline & December & January & February & & \\
\hline Sward height pre-grazing (m) & 1.62 & 1.72 & 1.77 & 1.72 & 0.09 \\
\hline Sward height post-grazing (m) & 0.97 & 1.34 & 1.25 & 1.19 & 0.21 \\
\hline Density $\left(\mathrm{kg} \mathrm{DM} \mathrm{ha}{ }^{-1} \mathrm{~cm}^{-1}\right)$ & 75.40 & 73.70 & 72.90 & 74.00 & 19.5 \\
\hline
\end{tabular}

${ }^{1}=$ Standard Deviation.

Table 4 - Chemical composition of hand plucked samples of 37 days rest elephant grass pasture.

\begin{tabular}{|c|c|c|c|c|c|}
\hline \multirow{2}{*}{ Components } & \multicolumn{3}{|c|}{ Periods of collection } & \multirow{2}{*}{ Mean } & \multirow{2}{*}{$\mathrm{SD}^{1}$} \\
\hline & December & January & February & & \\
\hline Dry matter & 14.27 & 17.06 & 14.56 & 15.30 & 1.53 \\
\hline Organic matter & 82.22 & 84.95 & 85.73 & 84.30 & 11.05 \\
\hline Crude Protein & 11.53 & 11.88 & 13.01 & 12.14 & 0.77 \\
\hline Neutral detergent fiber & 64.75 & 65.00 & 65.20 & 64.98 & 0.23 \\
\hline Acid detergent fiber & 36.92 & 37.00 & 37.20 & 37.04 & 0.14 \\
\hline Lignin & 3.08 & 2.92 & 2.03 & 2.67 & 0.36 \\
\hline Ether extract & 2.66 & 2.71 & 2.07 & 2.48 & 0.35 \\
\hline Ash & 17.78 & 15.05 & 14.27 & 15.70 & 1.84 \\
\hline IVDMD & 75.43 & 77.30 & 78.14 & 76.96 & 8.00 \\
\hline
\end{tabular}

\footnotetext{
${ }^{1}=$ standard deviation.
} 
reported $\mathrm{CP}$ values around 14 to $18.5 \%$ and TDN values from 60 to $65 \%$ TDN. In a recent study, Fontaneli (2005) reported 19 to $22 \%$ CP for elephant grass pasture fertilized with $500 \mathrm{~kg} \mathrm{ha}^{-1}$ of Nitrogen, grazed every 21-27 days.

The low TDN calculated according to NRC (2001) and those of Balsalobre (2002) do not agree with the high IVDMD reported in this trial and by Teixeira et al. (1999). The estimated TDN of 50\%, would not support an average milk production of 10 $\mathrm{kg} \mathrm{cow}^{-1}$, reported by Santos et al. (2003a, 2003b) for cows grazing tropical forage (pasture DMI of $2.37 \%$ of LBW) without concentrate. Cows with this pasture DMI, would require forage TDN of at least $60 \%$ to produce around $10 \mathrm{~kg}$ of milk day ${ }^{-1}$, according to NRC (2001).

The ash values reported in this trial $(15.7 \% \mathrm{~kg}$ DM) were extremely high. Balsalobre $(1996 ; 2002)$ also reported high ash values for tropical forages managed intensively, but not as much as those found here. Forage ash content has a great negative impact on forage TDN calculated using the equation incorporated by NRC (2001).

The pasture estimated TDN of $50.8 \%$ appears to be underestimated. On the other hand, the IVDMD of $76.9 \% \mathrm{~kg}$ DM may overestimate the pasture energy.

Average milk production of $18.3 \mathrm{~kg}$ of cows fed $6.3 \mathrm{~kg} \mathrm{~d}^{-1}$ of concentrate DM in this trial was lower than that reported in Santos et al. (2003a, 2003b), in which cows grazing tropical pastures milked $22.8 \mathrm{~kg}$ $\mathrm{d}^{-1}$ with 6.45 of by concentrate DM. Milk (17.88; $\left.18.37 ; 18.43 \mathrm{~kg} \mathrm{~d}^{-1}\right)$ and FCM $(17.37 ; 17.58 ; 17.75$ $\left.\mathrm{kg} \mathrm{d}^{-1}\right)$ yields were not affected $(P>0.05)$ by concentrate protein content (Table 5). This indicates that the NRC (2001) was a good tool to balance protein in the concentrate for mid lactating dairy cows grazing tropical forages. According to NRC (2001), 17\%CP e $21 \% \mathrm{CP}$ concentrates supplied excessive RDP and MP to these cows.

In Brazil, most of the farmers who manage well tropical pastures, feed concentrate with 20 to $24 \%$ $\mathrm{CP}(\% \mathrm{DM})$ for lactating dairy cows producing 15 to $25 \mathrm{~kg}$ of milk day ${ }^{-1}$. Santos et al. (2003a) reported CP contents in tropical pastures higher than the $12 \%$ observed in this study. Therefore, there is a good possibility to reduce feed costs when improving the diet formulation using the NRC (2001) in the Brazilian dairy farms.

Fontaneli (2005) fed only ground dry corn and mineral mix for lactating Holstein cows, grazing elephant grass, tifton 68 or kikuiu pastures with 19 to $22 \% \mathrm{CP}$ (\% DM) during two consecutive summers. Cows produced 20 and $25 \mathrm{~kg}$ of milk d $\mathrm{k}^{-1}$, respectively. Milk fat $(3.37 ; 3.27,3.30 \%)$, protein $(3.07 ; 3.12 ; 3.08 \%)$ lactose $(4.39 ; 4.40 ; 4.41 \%)$ and total solids $(11.73 ; 11.66 ; 11.70 \%)$ contents and yields were not affected $(P>0.05)$ by treatments (Table 5). Milk protein yield in high producing dairy cows (> $30 \mathrm{~kg} \mathrm{day}^{-1}$ ) is affected by the MP supply and by the MP amino acid profile (Schwab et al., 1976; Santos et al., 1998). Data from this trial indicate that the $17.3 \% \mathrm{CP}$ concentrate supplied enough RDP and MP for cows milking around $18.3 \mathrm{~kg} \mathrm{~d}^{-1}$, grazing tropical pastures.

Table 5 - Milk production (MP), milk composition, milk urea nitrogen, plasma urea nitrogen and chromium fecal concentration of lactating dairy cows grazing elephant grass pasture with three protein contents in the concentrate.

\begin{tabular}{|c|c|c|c|c|c|c|}
\hline \multirow{2}{*}{ Component } & \multicolumn{3}{|c|}{ Treatments } & \multirow[b]{2}{*}{$\mathrm{SEM}^{4}$} & \multirow[b]{2}{*}{$\mathrm{L}^{2}$} & \multirow[b]{2}{*}{$\mathrm{Q}^{3}$} \\
\hline & $17 \% \mathrm{CP}$ & $21 \% \mathrm{CP}$ & $25 \% \mathrm{CP}$ & & & \\
\hline Milk, $\left(\mathrm{kg} \mathrm{cow}^{-1}\right.$ day $\left.^{-1}\right)$ & 17.88 & 18.37 & 18.43 & 0.23 & 0.09 & 0.46 \\
\hline FCM-3.5\%, (kg cow ${ }^{-1}$ day $\left.^{-1}\right)$ & 17.37 & 17.58 & 17.75 & 0.31 & 0.38 & 0.92 \\
\hline Fat, \% & 3.37 & 3.27 & 3.30 & 0.01 & 0.38 & 0.38 \\
\hline Fat, kg day ${ }^{-1}$ & 0.59 & 0.59 & 0.60 & 0.01 & 0.58 & 0.77 \\
\hline Protein, \% & 3.07 & 3.12 & 3.08 & 0.03 & 0.72 & 0.29 \\
\hline Protein, kg day ${ }^{-1}$ & 0.54 & 0.56 & 0.55 & 0.01 & 0.13 & 0.26 \\
\hline Lactose, $\%$ & 4.39 & 4.40 & 4.41 & 0.06 & 0.44 & 0.95 \\
\hline Lactose, $\mathrm{kg}$ day $^{-1}$ & 0.79 & 0.81 & 0.81 & 0.01 & 0.09 & 0.42 \\
\hline Total solids, $\%$ & 11.73 & 11.66 & 11.70 & 0.05 & 0.43 & 0.60 \\
\hline Total solids, kg day ${ }^{-1}$ & 2.08 & 2.13 & 2.14 & 0.03 & 0.18 & 0.65 \\
\hline MUN, mg dL-1 & 11.17 & 13.93 & 15.63 & 0.38 & 0.01 & 0.28 \\
\hline PUN, mg dL ${ }^{-1}$ & 18.57 & 19.93 & 21.99 & 1.58 & 0.004 & 0.64 \\
\hline Chromium concentration, $\mathrm{mg} \mathrm{kg}^{-1}$ & 1.90 & 1.87 & 1.85 & 0.05 & 0.26 & 0.60 \\
\hline
\end{tabular}

${ }^{1}$ - probability, ${ }^{2}$ - linear effect, ${ }^{3}$ - quadratic effect, ${ }^{4}$ - standard error of de mean. $\mathrm{CP}=$ Crude Protein 
Increasing concentrate $\mathrm{CP}$ by feeding extra soybean meal beyond the NRC (2001) recommendation increased milk urea nitrogen (MUN) linearly $(P<0.05)\left(11.17 ; 13.9 ; 15.63 \mathrm{mg} \mathrm{dL}^{-1}\right)$. This increase in MUN without an increase in milk yield and composition, indicates a poor utilization of this extra protein in the concentrate. The MUN observed for the control diet is in the range considered adequate for cows milking around $18 \mathrm{~kg}$ of milk day ${ }^{-1}$. Excessive MUN concentrations indicate that nitrogen is being wasted. Reproductive efficiency can be compromised and negative environmental impacts may occur when excess protein is offered (Fergusson et al., 1988).

Plasma urea N (PUN) concentrations (18.57; $19.93 ; 21.99)$ increased linearly $(P<0.05)$ as concentrate CP increased. This is in agreement with MUN concentrations trends and confirms that feeding MP and RDP beyond NRC (2001) recommendations was excessive for cows milking around $18.3 \mathrm{~kg}$ of milk $\mathrm{day}^{-1}$, grazing elephant grass. The PUN values for the $17 \% \mathrm{CP}$ and $21 \% \mathrm{CP}$ concentrates were around the critical ones for negative effects on reproductive performance (Fergusson et al., 1988).

There were no effects of treatments $(P>0.05)$ on fecal chromium concentration in feces. This suggests that DMI was not affected by treatments. Body condition score and live weight variations were not affected by treatments $(P>0.05)$ (Table 6). Cows gained $0.28 \mathrm{BCS}$ (2.54 to 2.82) and $35 \mathrm{~kg}$ of LBW (511 to $546 \mathrm{~kg}$ ) during the 60 days experimental period. Is was observed that cows producing around 18.3 $\mathrm{kg}$ of milk day ${ }^{-1}$, grazing elephant grass and fed 6.3 $\mathrm{kg}$ of concentrate DM according to NRC (2001), were able to gain BCS during mid lactation.

The performance data observed in this trial indicate that energy and not protein is the major limiting nutrient in high production elephant grass for lactating dairy cows.

Treatments did not affect ingestive behavior of lactating cows grazing tropical pastures with $12 \% \mathrm{CP}$ (Table 7). Grazing time, rumination and idle time were not different for the treatments $(P>0.05)$. The values presented on Table 8 are in agreement with other data for lactating cows grazing elephant grass (Lucci et al., 1972; Lima, 2002).

Cows presented three peaks for grazing, from $9 \mathrm{~h} 30$ to $12 \mathrm{~h} 00$, from $18 \mathrm{~h} 30$ to $21 \mathrm{~h} 00$ and from $2 \mathrm{~h} 00$ to $4 \mathrm{~h} 00$ (Figure 1). Most of the grazing activity occurred at night and early morning, when environmental temperatures were lower. Grazing activity from $9 \mathrm{~h} 30$ to $12 \mathrm{~h} 00$ is not common for dairy cows in tropical areas. Morning milking was initiated late, at $07 \mathrm{~h} 00$ and delayed the cows to graze after milking.

Treatments did not affect $(P>0.05)$ cow rectal temperatures and respiratory rates (Table 8 ). By 8:00h cows were not under heat stress conditions, presenting a rectal temperature of $37.56^{\circ} \mathrm{C}$ and a respiratory frequency of 48.53 (Table 8 ). These values raised dramatically at $15 \mathrm{~h} 00$. The rectal temperature $\left(39.3^{\circ} \mathrm{C}\right)$ and respiratory rate (72.4) indicate that cows were heat stressed. Grazing activity from $9 \mathrm{~h} 30$ up to $12 \mathrm{~h} 00$ in the morning and shaded area with young trees, contributed to increase the heat stress of the cows.

Table 6 - Initial live weight (LWi), live weight variation (LWv) in periods of 20 days and initial body condition score (BCSi) and body condition score variation (BCSv) of dairy cows receiving three levels of protein in concentrate grazing elephant grass.

\begin{tabular}{|c|c|c|c|c|c|c|}
\hline \multirow{2}{*}{ Component } & \multicolumn{3}{|c|}{ Treatments } & \multirow[b]{2}{*}{$\mathrm{SEM}^{4}$} & \multirow[b]{2}{*}{$\mathrm{L}^{2}$} & \multirow[b]{2}{*}{$\mathrm{Q}^{3}$} \\
\hline & $17 \% \mathrm{CP}$ & $21 \% \mathrm{CP}$ & $25 \% \mathrm{CP}$ & & & \\
\hline LWi, kg & 511 & 502 & 521 & - & - & - \\
\hline LWv, kg & 13.50 & 8.60 & 14.67 & 5.87 & 0.88 & 0.47 \\
\hline BCSi, points & 2.56 & 2.69 & 2.38 & - & - & - \\
\hline BCSv, points & 0.04 & 0.14 & 0.08 & 0.06 & 0.65 & 0.38 \\
\hline
\end{tabular}

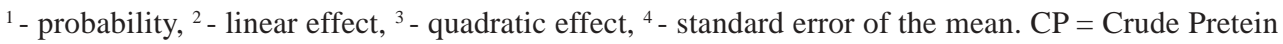

Table 7 - Grazing, ruminating and resting time of lactating dairy cows in elephant grass pasture fed concentrates with increasing CP contents.

\begin{tabular}{|c|c|c|c|c|c|c|}
\hline \multirow{2}{*}{ Component } & \multicolumn{3}{|c|}{ Treatments } & \multirow[b]{2}{*}{$\mathrm{SEM}^{4}$} & \multirow[b]{2}{*}{$\mathrm{L}^{2}$} & \multirow[b]{2}{*}{$\mathrm{Q}^{3}$} \\
\hline & $17 \% \mathrm{CP}$ & $21 \% \mathrm{CP}$ & $25 \% \mathrm{CP}$ & & & \\
\hline Grazing time (hours day ${ }^{-1}$ ) & 7.24 & 7.17 & 7.27 & 0.32 & 0.95 & 0.84 \\
\hline Ruminating time (hours day ${ }^{-1}$ ) & 8.33 & 7.80 & 8.06 & 0.27 & 0.47 & 0.26 \\
\hline Resting time (hours day-1) & 3.25 & 3.85 & 3.49 & 0.27 & 0.53 & 0.18 \\
\hline
\end{tabular}

${ }^{1}$ - probability, ${ }^{2}$ - linear effect, ${ }^{3}$ - quadratic effect, ${ }^{4}$ - standard error of the mean. $\mathrm{CP}=$ Crude Protein 
Table 8 - Rectal temperature (RT) and respiratory frequency (RF) of lactating dairy cows in elephant grass pasture receiving three protein supplementations, during summer.

\begin{tabular}{lcccccc}
\hline \multirow{2}{*}{ Component } & \multicolumn{3}{c}{ Treatments } & & \\
\cline { 2 - 5 } & $17 \% \mathrm{CP}$ & $21 \% \mathrm{CP}$ & $25 \% \mathrm{CP}$ & $\mathrm{SEM}^{4}$ & $\mathrm{~L}^{2}$ & $\mathrm{Q}^{3}$ \\
\hline $\mathrm{RT}\left({ }^{\circ} \mathrm{C}\right)^{5}$ & 37.54 & 37.50 & 37.63 & 0.08 & 0.47 & 0.44 \\
$\mathrm{RT}\left({ }^{\circ} \mathrm{C}\right)^{6}$ & 39.29 & 39.47 & 39.16 & 0.12 & 0.46 & 0.12 \\
$\mathrm{RF}(\mathrm{resp} / \mathrm{min})^{5}$ & 49.0 & 50.4 & 46.2 & 2.3 & 0.38 & 0.34 \\
$\mathrm{RF}(\mathrm{resp} / \mathrm{min})^{6}$ & 71.8 & 72.1 & 73.3 & 2.0 & 0.60 & 0.86 \\
\hline
\end{tabular}

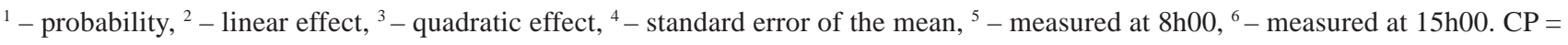
Crude Protein

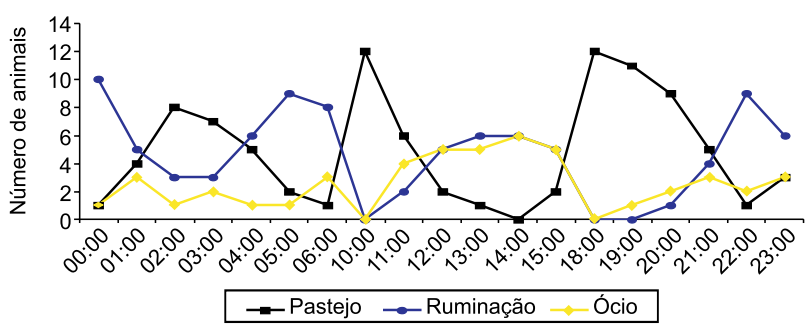

Figure 1 - Grazing, ruminating and resting times in a 24 hours period for lactating dairy cows grazing elephant grass pasture, during summer.

\section{CONCLUSIONS}

Balancing ration MP and RDP according to NRC (2001) is adequate for mid lactating cows grazing elephant grass containing 11 to $13 \% \mathrm{CP}$.

\section{ACKNOWLEDGEMENTS}

\section{To FAPESP for financial support.}

\section{REFERENCES}

AROEIRA, L.J.M.; LOPES, F.C.F.; DERESZ, F.; VERNEQUE, R.S.; DAYRELL, M.S.; MATOS, L.L.; MALDONADO-VASQUEZ, H. Pasture availability and dry matter intake of lactating crossbred cows grazing elephantgrass (Pennisetum purpureum Schum). Animal Feed Science and Technology, v.78, p.313324, 1999.

ASSOCIATION OF OFFICIAL ANALYTICAL CHEMISTS AOAC. Official methods of analysis. 12.ed. Washington, DC: AOAC, 1975. 1117p.

BALSALOBRE, M.A.A. Desempenho de vacas em lactação sob pastejo rotacionado de capim elefante (Pennisetum purpureum Shum.). Piracicaba: USP/ESALQ, 1996. 139p. Dissertação (Mestrado).

BALSALOBRE, M.A.A. Valor alimentar do capim Tanzânia irrigado. Piracicaba: USP/ESALQ, 2002. 113p. Tese (Doutorado).

CARARETO, R. Uso de uréia de liberação lenta para vacas alimentadas com silagem de milho ou pastagens de capim Elefante manejadas com intervalos fixos ou variáveis entre desfolhas. Piracicaba: USP/ESALQ, 2007. 113p. Dissertação (Mestrado)

CORSI, M.; MARTHA JR., G.B.; NASCIMENTO JR., D.; BALSALOBRE, M.A.A. Impact of grazing management on productivity of tropical grasslands. In: INTERNATIONAL GRASSLAND CONGRESS, 19., São Pedro, 2001. Proceedings. São Pedro, SBZ, 2001. p.801-805.
FERGUSSON, J.D.; BLANCHARD, T.; GALLIGAN, D.T.; HOSHALL, D.C.; CHALUPA, W. Infertility in dairy cattle fed a high percentage of protein degradable in the rumen. Journal of American Veterinarian Medical Association, v.192, p.659-662, 1988.

FONTANELI, R.S. Produção de leite de vacas da raça Holandesa em pastagens tropicais perenes no planalto médio do Rio Grande do Sul. Porto Alegre: UFRGS/Faculdade de Agronomia, 2005. 174p. Tese (Doutorado).

GOERING, H.K.; SOEST, P.J. van. Forage fiber analysis. Washington, D.C.: USDA/ARS, 1970. 20p. (Handbook, 379).

HILLESHEIM, A. Fatores que afetam o consumo e perdas de capimelefante (Pennisetum purpureum Schum.) sob pastejo. Piracicaba: USP/ESALQ, 1987. 94p. Dissertação (Mestrado).

LIMA, M.L.P. Produção de leite de vacas mestiças em pastagem de Capim-Elefante cv. Guaçu (Pennisetum purpureum Schum. Cv. Guaçu) e Capim Tanzânia (Panicum maximum Jacq. Cv. Tanzânia). Jaboticalbal: UNESP/FCAV, 2002. 102p. Dissertação (Mestrado).

LUCCI, C.S.; ROCHA, G.L.; FREITAS, E.A.N. Observações sobre hábitos de vacas leiteiras em pastos de capim fino e de capim Napier. Boletim da Indústria Animal, v.29, p.45-51, 1972.

MARTINEZ, J.C. Substituição do milho moído fino por polpa cítrica peletizada no concentrado de vacas leiteiras mantidas em pastagens de capim Elefante durante o outono-inverno. Piracicaba: USP/ESALQ, 2004. 110p. Dissertação (Mestrado).

NATIONAL RESEARCH COUNCIL - NRC. Nutrient requeriments of dairy cattle. 5.ed. Washington, D.C.: National Academic Press, 1978.

NATIONAL RESEARCH COUNCIL - NRC. Nutrient requeriments of dairy cattle. 6.ed. Washington, D.C.: National Academic Press, 1989.

NATIONAL RESEARCH COUNCIL - NRC. Nutrient requirements of dairy cattle. 7.ed. Washington, D.C.: National Academy Press, 2001.

NASCIMENTO FILHO, V.F. Técnicas analíticas nucleares de fluorescência de raios $X$ por dispersão de energia (EDXRF) e por reflexão total (TXRF). Piracicaba: USP/CENA, 1999. 32p. Available at http://web.cena.usp.br/apostilas/Virgilio/cen5723/EDXRF_TXRF.doc. Accessed 21 Oct. 2005.

PENATI, M.A.; CORSI, M.; DIAS, C.T.S.; MAYA, F.L.A. Efeito do número de amostras e da relação dimensão-formato da moldura sobre o coeficiente de variação na determinação da massa de forragem em pastagens de capim Tanzânia. In: REUNIÃO ANUAL DA SOCIEDADE BRASILEIRA DE ZOOTECNIA, 38., Piracicaba, 2001. Anais. Piracicaba: SBZ, 2001. p.46.

ROSSETO, F.A.A. Desempenho agronômico de plantas forrageiras em dois sistemas de produção de leite baseados nos de pastagem de capim elefante cv. Guaçu (Pennisetum purpureum) e capim Tanzânia (Panicum maximum). Piracicaba: USP/ESALQ, 2000. 221p. Dissertação (Mestrado).

SANTOS, F.A.P.; HUBER, J.T.; THEURER, C.B.; SWINGLE, R.S.; SIMAS, J.M.; CHEN, K.H.; YU, P. Milk yield and composition of lactating cows fed steam-flaked sorghum and graded concentrations of ruminally degradable protein. Journal of Dairy Science, v.81, p.215-220, 1998. 
SANTOS, F.A.P.; JUCHEM, S.O. Sistemas de produção de leite a base de forrageiras tropicais. In: FONTANELLI, R.R.; DÜRR, J.W. (Coord.). Sistemas de produção de leite. Passo Fundo: Editora da Universidade de Passo Fundo, 2000. 22-36p.

SANTOS, F.A.P.; MARTINEZ, J.C.; VOLTOLINI, T.V.; NUSSIO, C.M.B. Associação de plantas forrageiras de clima temperado e tropical em sistemas de produção animal de regiões sub-tropicais. In: SIMPÓSIO SOBRE MANEJO DA PASTAGEM; PRODUÇÃO ANIMAL EM PASTAGEM, SITUAÇÃO ATUAL E PERSPECTIVAS, 20., Piracicaba, 2003. Anais. Piracicaba: FEALQ, 2003a. p.215.

SANTOS, F.A.P.; MARTINEZ, J.C.; VOLTOLINI, T.V.; NUSSIO, C.M.B. Utilização da suplementação com concentrado para vacas em lactação mantidas em pastagens tropicais. In: SIMPÓSIO GOIANO SOBRE MANEJO E NUTRIÇÃO DE BOVINOS DE CORTE E LEITE, 5., Goiânia, 2003. Anais. Goiânia: CBNA, 2003b. p.289-346.

SAS INSTITUTE. User's guide: statistcs. Cary: SAS Institute, 1999. 965p.

SCHWAB, C.G.; SATTER, L.D.; CLAY, A.B. Response of lactating dairy cows to abomasal infusion of amino acids. Journal of Dairy Science, v.59, p.1254-1270, 1976.

SILVA, S.C. Manejo do pastejo para a obtenção de forragem de qualidade. In: SIMPÓSIO GOIANO SOBRE MANEJO E NUTRIÇÃO DE BOVINOS DE CORTE E LEITE, 7., Goiânia, 2005. Anais. Goiânia: CBNA, 2005. p.117-146.
SOEST, P.J. van. Nutritional ecology of the ruminant. 2 ed. Ithaca: Cornell University Press, 1994. p.140-155.

STOBBS, T.H. Short-term effects of herbage allowance on milk production, milk composition and grazing time of cows grazing nitrogen-fertilized tropical grass pasture. Australian Journal of Experimental Agriculture and Animal Husbandry, v.17, p.892-898, 1977.

TEIXEIRA, E.I.; MATTOS, W.R.S.; CAMARGO, A.C.C. Avaliação da produção e utilização de uma pastagem de capim Tobiatã (Panicum maximum cv. Tobiatã) sob pastejo rotacionado. Scientia Agricola, v.56, p.349-355, 1999.

VOLTOLINI, T.V. Adequação protéica em rações com pastagens ou com cana-de-açúcar e efeito de diferentes intervalos entre desfolhas da pastagem de capim elefante sobre o desempenho lactacional de vacas leiteiras. Piracicaba: USP/ESALQ, 2006. 167p. Tese (Doutorado)

WILDMAN, E.E.; JONES, G.M.; WAGNER, P.E.; BOMAN, R.L.; TROUTT, H.F.; LESCH, T.N. A dairy cow body condition scoring system and its relationship to standard production characteristics. Journal of Dairy Science, v.65, p.495-501, 1982.

Received February 17, 2006

Accepted November 14, 2007 